\title{
PEMBELAJARAN DIRECT INSTRUCTION MELALUI MEDIA VIDEO TERHADAP KETERAMPILAN PRAKTIK SHALAT BERJAMAAH
}

\author{
Maslani \\ maslani@uinsgd.ac.id \\ Muhamad Risman Maulana \\ rismanmaulana@uinsgd.ac.id \\ Jurusan Pendidikan Agama Islam, \\ UIN Sunan Gunung Djati Bandung
}

\begin{abstract}
The purpose of this study was to determine the effect of Direct Instruction learning model through video media on prayer practice skills in congregations in the treated class and those who were not treated. This study used the quasi-experimental method and nonequivalent control group design using two existing classes as samples, Experiments and Control Classes. The technique used to collect quantitative data is in the form of a test. The test is given twice, namely Pretest and Posttest. While for analyzing and processing data is done by statistical techniques. The results of this study were obtained from the use of Direct Instruction models through video media in the class that received treatment obtained by increasing student learning outcomes by $20.99 \%$ while those in classes that did not get treatment with conventional models obtaining $19.98 \%$ of this data was tested by analyzing data in the form of two average differences obtained by Zhitung 4.31> Ztable 1,645 so that it counts> Ztable. This data shows there are differences in influence between classes received treatment and classes that were not treated. Thus, it can be concluded that there is a significant influence on prayer practice skills in congregation by using the Direct Instruction model through video media for class VII students of SMP Negeri 2 Ciparay.
\end{abstract}




\section{Keywords: Direct Instruction and Video Media}

\section{A. Pendahuluan}

Shalat merupakan ibadah yang fundamental bagi umat islam dan shalat dalam agama islam adalah ibadah paling utama dan pertama yang diperhitungkan oleh Allah SWT. Amal ibadah yang menjadi ukuran baik buruknya amalan seseorang. Jika baik shalatnya, maka baik pula amalnya, namun jika buruk shalatnya, buruk pula seluruh amalnya. Ini berarti shalat menjadi variabel utama dalam amalan seorang muslim. Mengajarkan shalat kepada anak-anak memerlukan kesabaran dan waktu yang tidak pendek Sejak anak berusia tujuh tahun sudah harus belajar shalat sehingga pada usia sepuluh tahun diharapkan shalatnya menjadi lancar dan tertib. Disiplin melaksanakan shalat memerlukan juga pengawasan dari orang tua dan guru. Fungsi guru agama Islam selain sebagai pengajar dan pengawas, juga sebagai peneliti dalam melaksanakan ibadah. Karena itu pelaksanaan ibadah shalat di sekolah memerlukan pengawasan dan latihan dari guru agama.

Sebagai amalan yang paling utama, shalat sebaiknya dilaksanakan secara berjamaah karena derajatnya lebih besar dari pada shalat tidak berjamaah, karena shalat berjamaah yaitu, apabila dua orang shalat bersama-sama dan salah seorang di antara mereka mengikuti yang lain, keduanya dinamakan salat berjamaah. Orang yang diikuti (yang di hadapan) dinamakan imam, sedangkan yang mengikuti dibelakang dinamakan makmum." Shalat berjamaah lebih baik dibandingkan dengan shalat sendirian (munfarid) dan derajatnya lebih besar dibandingkan shalat sendiri. (H.Sulaiman Rasjid, 2014:106)

Namun banyak orang yang mengabaikannya karena mereka tidak mengetahui dan kurang meyakini bahwa hikmah yang terkandung dalam shalat berjamaah itu sendiri. Seperti hal-nya di lingkungan pendidikan, pada mata pelajaran pendidikan agama dan budi pekerti terdapat materi tentang shalat berjamaah peserta didik diajarkan berbagai pengetahuan tentang shalat berjamaah tetapi tidak cukup hanya dengan pengetahuan saja melainkan peserta didik pun diajarkan pula dalam praktiknya karena praktik berpacu terhadap psikomotorik dan nantinya akan menimbulkan hasil sikap dan keterampilan khususnya keterampilan dalam shalat berjamaah. 
Berdasarkan studi pendahuluan yang telah dilaksanakan oleh peneliti di kelas VII SMP Negeri 2 Ciparay Bandung bahwa pembelajaran PAI di setiap kelas terlaksana dengan baik. Tetapi pada saat pembelajaran praktik shalat berjamaah hasil pembelajarannya belum menunjukan kualitas yang tinggi, rendah dan kurang terampil, hal ini terlihat dari hasil ketercapaian siswa pada saat belajar praktik shalat berjamaah terutama kelas VII C dan kelas VII A rata-rata hasil yang didapat adalah 72,00 sementara nilai kkm yaitu, 76,00 kemudian ditambah dengan permasalahan lain yaitu, bacaan shalat masih ada yang belum hafal, posisi gerakan shalat masih ada yang salah, pengaturan shaf masih ada yang belum lurus, dalam praktiknya sebagian peserta didik masih kurang serius. Kemudian proses pembelajaran tersebut berlangsung monoton kurangnya guru dalam menggunakan media pembelajaran sehingga pada saat praktik shalat berjamaah siswa hanya mengikuti arahan guru.

Rendahnya hasil ketercapaian siswa pada praktek shalat berjamaah merupakan tantangan tersendiri bagi guru PAI di SMP Negeri 2 Ciparay. kemudian dalam upaya mencari solusi yang tepat terhadap permasalahan pada keterampilan praktik shalat berjamaah peneliti mencoba menggunakan model pembelajaran Direct Instruction dan Media Video. Model Direct Instruction (pembelajaran langsung) adalah pembelajaran menentukan informasi atau membangun keterampilan tahap demi tahap (Abdul Majid 2015:73). Kemudian media video adalah segala sesuatu yang memungkinkan sinyal audio dapat dikombinasikan dengan gambar bergerak secara sekuensial. Materi yang memerlukan visualisasi seperti, mendemonstrasikan hal-hal seperti gerakan motorik tertentu. (Daryanto 2011:79) dan untuk solusi tersebut cocok untuk membangun atau meningkatkan keterampilan peserta didik khususnya pada praktik shalat berjamaah.

Direct Instruction adalah pembelajaran yang banyak diarahkan oleh guru. Model ini efektif untuk menentukan informasi atau membangun keterampilan tahap demi tahap. Pembelajaran langsung biasanya bersifat deduktif. Direct intruction berpusat pada guru, dan menguji keterampilan siswa melalui latihan-latihan dibawah bimbingan dan arahan guru (Abdul Majid, 2015: 73). Dari ketiga ahli diatas Peneliti menganalis bahwa Direct Instruction digunakan dalam pembelajaran dengan rancangan khusus yang di dalamnya berkaitan dengan pengetahuan deklaratif dan pengetahuan prosedural dengan tahap demi tahap. 
Selain dari ketiga ahli diatas peneliti mencoba mengambil dari berbagai jurnal. Pada jurnal yang pertama mengemukakan bahwa Model Direct Instruction adalah suatu pendekatan mengajar yang membantu siswa mempelajari berbagai keterampilan dasar yang dapat diajarkan secara langkah demi langkah (Usman 2013: 321). Kemudian ada juga yang mengemukakan Direct Instruction merupakan suatu pendekatan yang dirancang khusus untuk menunjang proses belajar siswa yang berkaitan dengan pengetahuan prosedural dan pengetahuan deklaratif yang terstruktur dengan baik (Wawan Setiawan,dkk, 2010: 8).

\section{B. Metodologi Penelitian}

Pendekatan penelitian yang digunakan dalam penelitian ini adalah pendekatan kuantitatif, dengan menggunakan metode eksperimen desain Nonequivalent control group design. Jenis data yang dihimpun dalam penelitian ini meliputi data kualitatif dan data kuantitatif. Data kualitatif dikumpulkan dengan cara observasi dan wawancara seperti, sejarah berdirinya sekolah, letak geografis dan proses pembelajaran. Kemudian data kuantitatif yaitu, jenis data yang dapat diukur atau dihitung dan dinyatakan dengan bilangan yang berbentuk angka seperti, pretest, posttest dan hasil angket. Pada penelitian ini, peneliti mengambil lokasi di SMP Negeri 2 Ciparay Bandung. Populasi penelitian ini adalah siswa kelas VII SMP Negeri 2 Ciparay Bandung semester genap yang terdiri dari 10 kelas dengan jumlah 409 siswa. Sampel yang digunakan dalam penelitian ini yaitu, teknik sampling purposive dimana teknik ini menentukan sample dengan pertimbangan tertentu. Proses pengambilan sampel ini, peneliti mendatangi langsung lokasi penelitian dengan menemui guru PAI dan menentukan sampel yang akan dijadikan penelitian, kemudian guru PAI menyarankan untuk memakai kelas unggulan yaitu, kelas VII-C Sebanyak 41 orang dan kelas VII-A sebanyak 43 orang. Atas dasar saran guru PAI tersebut, peneliti mempertimbangkannya

\section{Hasil dan Pembahasan}

\section{a. Pembelajaran menggunakan Model Direct Instruction melalui media video terhadap kelas yang mendapat perlakuan}

Proses pembelajaran menggunakan model Direct Instruction dilaksanakan dengan 2 kali pertemuan yaitu, tanggal 9 Mei 2017 dan 16 Mei 2017. Pada tanggal 9 Mei 2017 dilakukan proses pembelajaran 
pertemuan ke-1, pertemuan ke-1 ini, peneliti memberikan tes awal dan tes akhir (pretest dan posttest) berbentuk soal pilihan ganda untuk mengetahui sejauh mana pemahaman peserta didik tentang materi shalat berjamaah sebelum dan sesudah pembelajaran, pemberian lembar sikap spiritual, dan pembelajaran dengan model Direct Instruction langkah-langkah sesuai susunan RPP tetapi proses pembelajaran di pertemuan ke-1 hanya uji simulasi awal RPP dan tidak ada sistem penilaian praktek. Penelitian ini dilakukan di kelas VII-C dengan jumlah peserta didik sebanyak 41 peserta didik di SMPN 2 Ciparay Kabupaten Bandung. Seluruh Peserta didik mengikuti proses pembelajaran PAI dan dilakukan dengan masing-masing alokasi waktu 3 x 40 menit.

Pada tanggal 16 Mei 2017 dilakukan pembelajaran pertemuan ke-2, pada proses pembelajaran pertemuan ke-2 ini peneliti memberikan kembali tes awal dan tes akhir (pretest dan posttest) berbentuk tes unjuk kerja untuk mengetahui kemampuan atau keterampilan praktek shalat berjamaah sebelum dan sesudah pembelajaran, pemberian lembar sikap sosial, mengulang materi pada pertemuan ke-1 dengan Model Direct Instruction langkah-langkah sesuai dengan RPP. Penelitian ini dilakukan di kelas VII-C dengan jumlah peserta didik sebanyak 41 peserta didik di SMPN 2 Ciparay Kabupaten Bandung dan yang mengikuti proses pembelajaran hanya 37 peserta didik dimana 4 orang berhalangan hadir dikarenakan izin dispensasi. Proses pembelajaran dilakukan dengan masing-masing alokasi waktu 3 x 40 menit. Pada segi pemahaman siswa Peneliti memberikan tes awal dan tes akhir (Pretest dan Posttest) dengan bentuk Pilihan Ganda Sebanyak 20 butir Soal kemudian pada segi praktek peneliti memberikan tes unjuk kerja yang dilakukan dalam tes awal dan tes akhir (pretest dan posttest). Proses pembelajaran jika dijabarkan adalah sebagai berikut:

\section{Kegiatan awal}

Kegiatan awal pada tahap ini berdurasi 10 menit, di awali dengan guru mengucapkan salam dan mengarahkan peserta didik untuk berdo'a sebelum memulai kegiatan belajar mengajar, guru mengecek kehadiran dan mempersiapkan peserta didik, guru memotivasi peserta didik, melakukan apersepsi dan memberikan lembar sikap (pertemuan ke-1 lembar sikap spiritual dan pada pertemuan ke-2 lembar sikap sosial), 
guru menjelaskan tujuan pembelajaran dan menentukan prosedur pengajaran dengan Model Direct Instruction dan guru memberikan pre-test (pada pertemuan ke-1 pretest berbentuk soal pilihan ganda dan pada pertemuan ke-2 pretest berbentuk tes unjuk kerja)

2 Kegiatan inti

Pada kegiatan inti berdurasi kurang lebih 100 menit dengan menggunakan pendekatan saintifik, kegiatan inti sebagai berikut:

a) Mengamati : Peserta didik memperhatikan representasi visual berupa video contoh gerakan shalat berjamaah, guru menjelaskan konsep tentang Shalat berjamaah.

b) Menanya : Peserta didik mengajukan pertanyaan mengenai tanyangan video tentang contoh gerakan shalat berjamaah, guru menjelaskan ulang hal yang dianggap sulit atau kurang dimengerti peserta didik (pemahaman).

c) Mengumpulkan Informasi : Peserta didik membentuk kelompok 4-7 orang dibimbing oleh guru, guru membimbing peserta didik dengan contoh praktik atau latihan-latihan awal, guru memberikan koreksi terhadap praktik yang salah dan memperkuat praktik yang telah benar.

d) Mengasosiasi : Guru menghubungkan kebiasaan shalat berjamaah dengan kepemimpinan.

e) Mengkomunikasikan : Guru meminta setiap kelompok untuk mempraktikan Shalat Berjamaah secara bergiliran, guru mengamati jalannya praktik, guru memberikan tanggapan balik berupa pujian maupun petunjuk kepada peserta didik, Peserta didik melakukan praktik mandiri, guru memonitoring siswa praktik mandiri.

\section{$3 \quad$ Kegiatan penutup}

Pada kegiatan ini berdurasi kurang lebih 10 menit dimana Peserta didik diberi kesempatan oleh guru untuk bertanya mengenai materi keseluruhan yang belum dimengerti, guru memberikan post-test 
(pada pertemuan ke-1 post-test berbentuk soal pilihan ganda dan pertemuan ke-2 post-test berbentuk tes unjuk kerja), guru dan peserta didik menyimpulkan pembelajaran, guru dan peserta didik menutup pembelajaran dengan berdo'a.

\section{b. Pembelajaran di kelas yang tidak mendapat perlakuan Model Direct Instruction}

Pada proses pembelajaran di kelas kontrol, guru tidak menerapkan treatment pembelajaran Direct Instruction akan tetapi siswa kelas kontrolpun diberi perlakuan hal yang sama yaitu, dengan menggunakan model Konvensional untuk mempraktekan shalat tersebut, tujuannya adalah agar siswa dapat menerapkan dikehidupan sehari-hari, jadi tidak kelompok eksperimen saja yang bisa menerapkan shalat itu, akan tetapi kelas kontrol pun bisa, walaupun secara garis besar kelompok kontrol tidak diberi arahan terlebih dahulu oleh guru.

Pada penelitian di kelas kontrol, peneliti hanya mengambil hasil dengan model konvensional, tetapi pengambilan hasil ini dilakukan dengan pembelajaran 2 kali pertemuan yaitu, tanggal 9 Mei 2017 dan 16 Mei 2017 pada jam ke dua setelah kelas yang diberi perlakuan. Pada tanggal 9 Mei 2017 dilakukan pembelajaran pertemuan ke-1, pertemuan ke-1 ini peneliti memberikan tes awal dan tes akhir (pre-test dan post-test) berbentuk soal pilihan ganda untuk mengetahui sejauh mana pemahaman peserta didik tentang materi shalat berjamaah sebelum dan sesudah pembelajaran, pemberian lembar sikap spiritual dan pembelajaran dengan model konvensional. Penelitian ini dilakukan di kelas VII-A dengan jumlah 43 peserta didik di SMPN 2 Ciparay Kabupaten Bandung. Peserta didik mengikuti proses pembelajaran hanya 41 orang dan 2 orang tidak mengikuti dikarenakan sakit. Proses pembelajaran dilakukan dengan masing-masing alokasi waktu 3 x 40 menit.

Pada tanggal 16 Mei 2017 dilakukan pembelajaran pertemuan ke-2, pada proses pembelajaran pertemuan ke-2 peneliti memberikan kembali tes awal dan tes akhir (pre-test dan post-test) berbentuk tes ujuk kerja untuk mengetahui kemampuan atau keterampilan praktek shalat berjamaah sesudah dan sebelum pembelajaran, pemberian lembar sikap sosial dan pemberian materi dengan model Konvensional. Penelitian ini dilakukan di kelas VII-A dengan jumlah 43 siswa di SMPN 2 Ciparay Kabupaten 
Bandung dan yang mengikuti proses pembelajaran hanya 37 karena 6 orang sakit dan izin Dispensasi. Pada segi pemahaman siswa peneliti memberikan tes awal dan tes akhir (Pre-test dan Post-test) dengan bentuk Pilihan Ganda sebanyak 20 butir Soal kemudian pada segi praktek peneliti memberikan tes unjuk kerja yang dilakukan dalam tes awal dan tes akhir (pre-test dan post-test).

\section{Realitas Keterampilan Praktik Shalat Berjamaah Terhadap Kelas} Yang Mendapat Perlakuan Model Pembelajaran Direct Instruction Melalui Media Video Dengan Kelas Yang Tidak Diberi Perlakuan Model Direct Instruction Melalui Media Video

\section{a. Realitas keterampilan praktik shalat berjamaah di kelas yang mendapat perlakuan Model Direct Instruction Melalui Video.}

Sebelum dilakukan atau diketahui realitas hasil dari keterampilan praktek shalat berjamaah. Peneliti melakukan penelitian secara bertahap dimana peneliti melihat dahulu realitas sikap spiritual, sikap sosial kemudian pemahaman peserta didik jika terjadi peningkatan maka dilanjutkan kepada keterampilan praktik, adapun realitas ini dimulai dari realitas sikap spritual yaitu, sebagai berikut:

\section{1) Realitas Sikap Spiritual di kelas yang diberi perlakuan}

a) Data Hasil Sikap Spiritual

Data hasil sikap spritual di kelas yang mendapat perlakuan yaitu, di kelas VII-C dengan jumlah peserta didik perkelas sebanyak 41 orang. Adapun data hasil penelitian ini melihat pada penilaian diri peserta didik. Penilaian spritual ini diberikan berupa penyataan-pernyataan yang disusun dengan menggunakan skala likert yaitu, sangat tidak setuju, tidak setuju, kurang setuju, setuju dan sangat setuju. Pada aspek spiritual ini mengacu kepada materi judul penelitian yaitu, mengenai shalat berjamaah. Deskripsi Rekapitulasi Sikap Spiritual di kelas VII C.

Pada deskripsi rekapitulasi ini akan dilakukan dengan berbentuk persentase dari setiap jawaban responden pada setiap item. Adapun deskripsi rekapitulasi sikap spiritual dikelas VII-C sebagai berikut:

(1) Jumlah responden pada penyataan Item pertama

Pada pernyataan pertama peneliti menggunakan pernyataan "Saya meyakini shalat berjamaah lebih baik dari shalat sendirian". Pada 
pernyataan ini jawaban responden sebanyak 9\% dari 4 responden menyatakan "kurang setuju", 12\% dari 5 responden menyatakan "setuju" dan $78 \%$ dari 32 responden menyatakan "sangat setuju". kemudian untuk jawaban "sangat tidak setuju” dan "tidak setuju” tidak ada yang menjawab atau menyatakan. Jawaban responden ini diambil peneliti dari keseluruhan jumlah peserta didik di kelas yang diberi perlakuan yaitu, kelas VII-C sebanyak 41 peserta didik. (perhitungan persentase terlampir).

(2)Jumlah responden pada penyataan Item ke-dua

Pada pernyataan ke-dua peneliti menggunakan pernyataan "Saya meyakini bahwa shalat yang benar dapat mencegah perbuatan tercela". Pada pernyataan ini jawaban responden sebanyak 4\% dari 2 responden menyatakan "sangat tidak setuju", 2\% dari 1 responden menyatakan "tidak setuju", 12\% dari 5 responden menyatakan "kurang setuju" kemudian 39\% dari 16 responden menyatakan "setuju" dan $41 \%$ dari 17 responden menyatakan "sangat setuju”. Jawaban responden diambil peneliti dari keseluruhan jumlah peserta didik di kelas yang diberi perlakuan yaitu kelas VII C sebanyak 41 peserta didik. (perhitungan persentase terlampir).

(3) Jumlah responden pada pernyataan item ke-tiga

Pada pernyataan ke-tiga peneliti menggunakan pernyataan "Karena besar pahala, saya akan melakukan shalat berjamaah setiap waktu dimana saja". Pada pernyataan ini jawaban responden sebanyak 2\% dari 1 responden menyatakan "tidak setuju”, 17\% dari 7 responden menyatakan "kurang setuju”, 65\% dari 27 responden menyatakan "setuju” dan 14\% dari 6 responden menyatakan "sangat setuju”. Kemudian yang menyatakan "sangat tidak setuju" tidak ada yang menyatakan atau menjawab. Jawaban responden diambil peneliti dari keseluruhan jumlah peserta didik di kelas yang diberi perlakuan yaitu kelas VII-C sebanyak 41 peserta didik. (perhitungan persentase terlampir)

(4)Jumlah responden pada pernyataan item ke-empat

Pada pernyataan ke-empat peneliti menggunakan pernyataan "Saya meyakini bahwa shalat berjamaah mengajarkan terhadap sikap disiplin". Pada pernyataan ini jawaban responden sebanyak 7\% dari 3 responden menyatakan "tidak setuju”, 7\% dari 3 responden menyatakan "kurang setuju”, 48\% dari 20 responden menyatakan "setuju” kemudian 36\% dari 
15 responden menyatakan "sangat setuju" dan untuk jawaban "sangat tidak setuju" tidak ada responden yang menyatakan atau menjawab. Jawaban responden ini diambil peneliti dari keseluruhan jumlah peserta didik di kelas yang diberi perlakuan yaitu kelas VII-C sebanyak 41 peserta didik. (perhitungan persentase terlampir).

(5)Jumlah responden pada pernyataan item ke-lima

Pada pernyataan ke-lima peneliti menggunakan pernyataan "Saya meyakini dengan melaksanakan shalat hati menjadi tentram". Pada pernyataan ini jawaban responden sebanyak 44\% dari 18 responden menyatakan "setuju" dan 56\% dari 18 responden menyatakan "sangat setuju”. Kemudian untuk jawaban "sangat tidak setuju”,"tidak setuju" dan "kurang setuju” tidak ada responden yang menjawab atau menyatakan. Jawaban responden diambil peneliti dari keseluruhan jumlah peserta didik di kelas yang diberi perlakuan yaitu kelas VII-C sebanyak 41 peserta didik. (perhitungan persentase terlampir).

Setelah didapatkan hasil Sikap Spiritual dilanjutkan kepada realitas sikap sosial untuk sikap sosial yaitu, sebagai berikut:

\section{Realitas Sikap Sosial Kelas Yang Diberi Perlakuan}

1) Data Hasil Sikap Sosial

Data hasil sikap sosial dikelas yang mendapat perlakuan yaitu kelas VII-C dengan jumlah peserta didik perkelas sebanyak empat puluh satu orang (41), dari 41 orang yang hadir hanya 37 orang dan yang tidak hadir sebanyak 4 orang dikarenakan izin dispensasi. Adapun data hasil penelitian ini dilakukan dengan penilaian antar teman peserta didik, penilaian sosial tidak jauh berbeda dengan spiritual, yaitu: diberikan berupa penyataanpernyataan yang disusun dengan menggunakan 4 skala (Selalu, Sering, Kadang-Kadang Dan Tidak Pernah). Deskripsi Rekapitulasi Sikap Sosial di kelas VII C

Sama seperti sikap spiritual yaitu, pada deskripsi rekapitulasi ini juga akan dilakukan dengan berbentuk persentase dari setiap penilaian responden terhadap temannya sendiri pada setiap item. Adapun deskripsi rekapitulasi sikap sosial dikelas VII-C sebagai berikut:

a) Jumlah yang menilai pada penyataan Item pertama

Pada pernyataan pertama peneliti menggunakan pernyataan "Taat kepada 
pemimpin di lingkungan kelas". Pada pernyataan ini sebanyak $8 \%$ dari 3 responden yang menilai temannya sendiri menyatakan "selalu", 10\% dari 4 responden yang menilai temannya sendiri menyatakan "sering", 70\% dari 26 responden yang menilai temannya sendiri menyatakan "kadangkadang" dan $10 \%$ dari 4 responden yang menilai temannya sendiri menyatakan "tidak pernah". Hasil data ini diambil dari kelas yang diberi perlakuan yaitu: kelas VII C sebanyak 37 peserta didik dari 41 peserta didik. (perhitungan persentase terlampir).

b) Jumlah yang menilai pada penyataan Item ke-dua

Pada pernyataan ke-dua peneliti menggunakan pernyataan "Peduli sesama di lingkungan kelas". Pada pernyataan ini sebanyak 16\% dari 6 responden yang menilai temannya sendiri menyatakan "selalu”, 13\% dari 5 responden yang menilai temannya sendiri menyatakan "sering", $62 \%$ dari 23 responden yang menilai temannya sendiri menyatakan "kadang-kadang" dan $8 \%$ dari 3 responden yang menilai temannya sendiri menyatakan "tidak pernah". Hasil data ini diambil dari kelas yang diberi perlakuan yaitu: kelas VII C sebanyak 37 peserta didik dari 41 peserta didik. (perhitungan persentase terlampir).

c) Jumlah yang menilai pada Penyataan Item ke-tiga

Pada pernyataan ke-tiga peneliti menggunakan pernyataan "Menasihati dalam kebenaran di lingkungan Kelas". Pada pernyataan ini sebanyak 13\% dari 5 responden yang menilai temannya sendiri menyatakan "selalu”, 13\% dari 5 responden yang menilai temannya sendiri menyatakan "sering”, 48\% dari 18 responden yang menilai temannya sendiri menyatakan "kadangkadang" dan 24\% dari 9 responden yang menilai temannya sendiri menyatakan "tidak pernah". Hasil data ini diambil dari kelas yang diberi perlakuan yaitu, kelas VII C sebanyak 37 peserta didik dari 41 peserta didik. (perhitungan persentase terlampir).

d) Jumlah yang menilai pada penyataan Item ke-empat

Pada pernyataan ke-empat peneliti menggunakan pernyataan "Memberi salam sebelum dan sesudah menyampaikan pendapat/persentasi". Pada pernyataan ini sebanyak $35 \%$ dari 13 responden yang menilai temannya sendiri menyatakan "selalu”, $10 \%$ dari 4 responden yang menilai temannya sendiri menyatakan "sering", 37\% dari 14 responden yang menilai temannya sendiri menyatakan "kadang-kadang" dan $16 \%$ dari 6 responden 
yang menilai temannya sendiri menyatakan “tidak pernah".Hasil data ini diambil dari kelas yang diberi perlakuan yaitu, kelas VII C sebanyak 37 peserta didik dari 41 peserta didik. (perhitungan persentase terlampir).

e) Jumlah yang menilai pada Penyataan Item ke-lima

Pada pernyataan ke-lima peneliti menggunakan pernyataan "Mengucapkan terimakasih setelah menerima bantuan orang lain". Pada pernyataan ini sebanyak 27\% dari 10 responden yang menilai temannya sendiri menyatakan "selalu", $31 \%$ dari 12 responden yang menilai temannya sendiri menyatakan "sering", 40\% dari 15 responden yang menilai temannya sendiri menyatakan "kadang-kadang" dan responden yang menilai temannya sendiri menyatakan "tidak pernah" tidak ada yang menyatakan atau menilai. Hasil data ini diambil dari kelas yang diberi perlakuan yaitu, kelas VII C sebanyak 37 peserta didik dari 41 peserta didik. (perhitungan persentase terlampir).

Setelah didapatkan hasil sikap sosial selanjutnya melihat hasil realitas pemahaman peserta didik di kelas VII-C, sebagai berikut:

\section{Realitas Pemahaman kelas yang diberi perlakuan}

Pemahaman Belajar Siswa di kelas yang diberi perlakuan, sebelum dan sesudah menggunakan Model Direct Instruction melalui tes pilihan ganda sebanyak 20 butir soal. Tes tersebut mendapatkan hasil sebagai berikut:

\section{Tabel 1. Hasil Pemahaman Sebelum dan Sesudah di kelas yang diberi perlakuan}

\begin{tabular}{|l|l|l|}
\hline Keterangan & Pretest & Posttest \\
\hline $\mathrm{N}$ & 41 & 41 \\
\hline Nilai Tertinggi & 75 & 95 \\
\hline Nilai Terendah & 30 & 60 \\
\hline Rata-Rata & 54,18 & 79,91 \\
\hline
\end{tabular}

Dari tabel 1. di atas adalah hasil pemahaman belajar siswa kelas VII-C menggunakan model Direct Instruction pada kegiatan Pretest memiliki nilai tertinggi 75 dan terendah 30, sedangkan rata-ratanya 54,18 kemudian pada kegiatan Post-Test memiliki nilai tertinggi 95 dan terendah 60, sedangkan rata-ratanya 79,91 . Jika terjadi peningkatan pada segi pemahaman maka dapat dilanjut kepada keterampilan praktek, adapun realitas keterampilan praktek, sebagai berikut: 
4 Realitas Keterampilan Praktik Shalat Berjamaah Kelas Yang Diberi Perlakuan

Realitas Keterampilan praktek shalat berjamaah peserta didik di kelas yang diberi perlakuan yaitu kelas VII-C Dengan Menggunakan Model Direct Intruction Sebelum dan sesudah melalui tes unjuk Kerja. Tes tersebut mendapatkan hasil sebagai berikut, dapat dilihat pada tabel 3.7 dibawah ini :

Tabel 2.Hasil keterampilan Praktek Shalat Berjamaah Sebelum dan Sesudah di kelas yang diberi perlakuan

\begin{tabular}{|l|l|l|}
\hline Keterangan & Pretest & Posttest \\
\hline $\mathrm{N}$ & 37 & 37 \\
\hline Nilai Tertinggi & 77 & 94 \\
\hline Nilai Terendah & 54 & 77 \\
\hline Rata-Rata & 64,79 & 85,78 \\
\hline
\end{tabular}

(Hasil Data Persiswa Terlampir)

Dari tabel 2. di atas adalah hasil praktek belajar siswa kelas VII-C menggunakan model Direct Instruction pada kegiatan Pretest memiliki nilai tertinggi 77 dan terendah 54, sedangkan rata-ratanya 64,79 kemudian pada kegiatan Post-Test memiliki nilai tertinggi 94 dan terendah 77 , sedangkan rata-ratanya 85,78 .

\section{b. Realitas Keterampilan Praktik Shalat Berjamaah Kelas Yang Tidak Diberi Perlakuan Model Direct Instruction Melalui Media Video}

Sama seperti kelas eksperimen, Sebelum dilakukan atau diketahui realitas hasil dari keterampilan praktek shalat berjamaah. Peneliti melakukan penelitian secara bertahap dimana peneliti melihat dahulu realitas sikap spiritual, sikap sosial kemudian pemahaman peserta didik jika terjadi peningkatan maka dilanjutkan kepada keterampilan praktik, adapun realitas ini dimulai dari sikap spritual yaitu, sebagai berikut:

\section{1) Realitas Sikap Spiritual di kelas yang tidak diberi perlakuan \\ a) Data Hasil Sikap Spiritual}

Data hasil sikap spritual di kelas yang tidak mendapat perlakuan yaitu kelas VII A dengan jumlah peserta didik per-kelas sebanyak 43 orang dan yang hadir hanya 41 orang. Adapun data hasil penelitian ini melihat 
pada penilaian diri peserta didik, penilaian spritual diberikan berupa penyataan-pernyataan yang disusun dengan menggunakan skala likert yaitu, sangat tidak setuju, tidak setuju, kurang setuju, setuju dan sangat setuju. Pada aspek spiritual ini mengacu kepada materi judul penelitian yaitu pada shalat berjamaah. Deskripsi rekapitulasi sikap spiritual di kelas VII A

Pada deskripsi rekapitulasi ini akan dilakukan dengan berbentuk persentase dari setiap jawaban responden pada setiap item. Adapun deskripsi rekapitulasi sikap spiritual dikelas VII-A sebagai berikut:

(1) Jumlah responden pada penyataan item pertama

Pada pernyataan pertama peneliti menggunakan pernyataan "Saya meyakini shalat berjamaah lebih baik dari shalat sendirian". Pada pernyataan ini jawaban responden sebanyak 2\% dari 1 responden menyatakan : "sangat tidak setuju”, 2\% dari 1 responden yang menyatakan "tidak setuju”, $12 \%$ dari 5 responden menyatakan, "kurang setuju”, 29\% dari 12 responden menyatakan "setuju”, 53\% dari 22 responden menyatakan "sangat setuju”. Jawaban responden diambil peneliti dari jumlah peserta didik yang hadir di kelas yang tidak diberi perlakuan yaitu: kelas VII A sebanyak 41 peserta didik yang hadir dari 43 peserta didik (Perhitungan persentase terlampir)

(2) Jumlah responden pada penyataan item ke-dua

Pada pernyataan ke-dua peneliti menggunakan pernyataan "Saya meyakini bahwa shalat yang benar dapat mencegah perbuatan tercela". Pada pernyataan ini jawaban responden sebanyak 2\% dari 1 responden menyatakan : "sangat tidak setuju”, 12\% dari 5 responden menyatakan, "kurang setuju”, 51\% dari 21 responden menyatakan "setuju”, dan 34\% dari 14 responden menyatakan "sangat setuju”. Kemudian untuk responden yang menyatakan "tidak setuju” tidak ada yang menyatakan atau menjawab. Jawaban responden ini diambil peneliti dari jumlah peserta didik yang hadir di kelas yang tidak diberi perlakuan yaitu: kelas VII A sebanyak 41 peserta didik yang hadir dari 43 peserta didik (Perhitungan persentase terlampir)

(3) Jumlah responden pada pernyataan item ke-tiga

Pada pernyataan ke-tiga peneliti menggunakan pernyataan "Karena 
besar pahala, saya akan melakukan shalat berjamaah setiap waktu dimana saja". Pada pernyataan ini jawaban responden sebanyak 4\% dari 2 responden yang menyatakan "tidak setuju”, 24\% dari 10 responden menyatakan, "kurang setuju", 31\% dari 13 responden menyatakan "setuju”, 39\% dari 16 responden menyatakan "sangat setuju”. kemudian responden yang menyatakan "sangat tidak setuju” tidak ada responden yang menjawab. Jawaban responden diambil peneliti dari jumlah peserta didik yang hadir di kelas yang tidak diberi perlakuan yaitu: kelas VII A sebanyak 41 peserta didik yang hadir dari 43 peserta didik (Perhitungan persentase terlampir)

(4) Jumlah responden pada pernyataan item ke-empat

Pada pernyataan ke-empat peneliti menggunakan pernyataan "Saya meyakini bahwa shalat berjamaah mengajarkan terhadap sikap disiplin". Pada pernyataan ini jawaban responden sebanyak 2\% dari 1 responden yang menyatakan "tidak setuju”, 12\% dari 5 responden menyatakan, "kurang setuju”, 39\% dari 16 responden menyatakan "setuju”, 46\% dari 19 responden menyatakan "sangat setuju”. kemudian responden yang menyatakan "sangat tidak setuju" tidak ada responden yang menjawab. Jawaban responden diambil peneliti dari jumlah peserta didik yang hadir di kelas yang tidak diberi perlakuan yaitu: kelas VII A sebanyak 41 peserta didik yang hadir dari 43 peserta didik (Perhitungan persentase terlampir)

(5) Jumlah responden pada pernyataan item ke-lima

Pada pernyataan ke-lima peneliti menggunakan pernyataan "Saya meyakini dengan melaksankan shalat hati menjadi tentram". Pada pernyataan ini jawaban responden sebanyak 2\% dari 1 responden yang menyatakan "tidak setuju”, 4\% dari 2 responden menyatakan, "kurang setuju", 26\% dari 11 responden menyatakan "setuju” dan 65\% dari 27 responden menyatakan "sangat setuju”. kemudian responden yang menyatakan "sangat tidak setuju” tidak ada responden yang menjawab. Jawaban responden diambil peneliti dari jumlah peserta didik yang hadir di kelas yang tidak diberi perlakuan yaitu: kelas VII A sebanyak 41 peserta didik yang hadir dari 43 peserta didik.Setelah didapatkan hasil Sikap Spiritual dilanjutkan kepada realitas sikap sosial untuk sikap sosial, sebagai berikut: 


\section{2) Realitas Sikap Sosial kelas yang tidak diberi perlakuan}

a) Data Hasil Sikap Sosial

Data hasil sikap sosial, di kelas yang tidak mendapat perlakuan yaitu: kelas VII-A dengan jumlah peserta didik per-kelas sebanyak 43 peserta didik dan yang hadir hanya 37 pesert didik. Adapun data hasil penelitian ini dilakukan dengan penilaian antar teman, penilaian sosial tidak jauh berbeda dengan spiritual, yaitu: diberikan berupa penyataan-pernyataan yang disusun dengan menggunakan 4 skala (Selalu, Sering, KadangKadang Dan Tidak Pernah). Deskripsi Rekapitulasi Sikap Sosial di kelas VII A. Sama seperti sikap spiritual yaitu, pada deskripsi rekapitulasi ini juga akan dilakukan dengan berbentuk persentase dari setiap jawaban responden pada setiap item. Adapun deskripsi rekapitulasi sikap sosial dikelas VII-A sebagai berikut:

(1)Jumlah yang menilai pada Penyataan Item pertama

Pada pernyataan pertama peneliti menggunakan pernyataan "Taat kepada pemimpin di lingkungan kelas". Pada pernyataan ini sebanyak 5\% dari 2 responden yang menilai temannya sendiri menyatakan "selalu", $21 \%$ dari 8 responden yang menilai temannya sendiri menyatakan "sering", $64 \%$ dari 24 responden yang menilai temannya sendiri menyatakan "kadang-kadang" dan $10 \%$ dari 4 responden yang menilai temannya sendiri menyatakan "tidak pernah". Hasil data ini diambil dari jumlah peserta didik yang hadir di kelas yang tidak diberi perlakuan yaitu, kelas VII A yang hadir sebanyak 37 dari 43 peserta didik. Jumlah yang menilai pada Penyataan Item kedua

(2)Pada pernyataan ke-dua peneliti menggunakan pernyataan "Peduli sesama di lingkungan kelas". Pada pernyataan ini sebanyak $13 \%$ dari 5 responden yang menilai temannya sendiri menyatakan "selalu”, 24\% dari 9 responden yang menilai temannya sendiri menyatakan "sering", $54 \%$ dari 20 responden yang menilai temannya sendiri menyatakan "kadang-kadang" dan $8 \%$ dari 3 responden yang menilai temannya sendiri menyatakan "tidak pernah". Hasil data ini diambil dari jumlah peserta didik yang hadir di kelas yang tidak diberi perlakuan yaitu, kelas VII A yang hadir sebanyak 37 dari 43 peserta didik. Jumlah yang menilai pada Penyataan Item ke-tiga.

Pada pernyataan ke-tiga peneliti menggunakan pernyataan 
“Menasihati dalam kebenaran di lingkungan Kelas". Pada pernyataan ini sebanyak $10 \%$ dari 4 responden yang menilai temannya sendiri menyatakan "selalu", 29\% dari 11 responden yang menilai temannya sendiri menyatakan "sering", 43\% dari 16 responden yang menilai temannya sendiri menyatakan "kadang-kadang" dan 16\% dari 6 responden yang menilai temannya sendiri menyatakan "tidak pernah". Hasil data ini diambil dari jumlah peserta didik yang hadir di kelas yang tidak diberi perlakuan yaitu: kelas VII A yang hadir sebanyak 37 dari 43 peserta didik. (perhitungan pesentase terlampir)

(3) Jumlah yang menilai pada Penyataan Item ke-empat

Pada pernyataan ke-empat peneliti menggunakan pernyataan "Memberi salam sebelum dan sesudah menyampaikan pendapat/ persentasi”. Pada pernyataan ini sebanyak $24 \%$ dari 9 responden yang menilai temannya sendiri menyatakan "selalu", 18\% dari 7 responden yang menilai temannya sendiri menyatakan "sering", 37\% dari 14 responden yang menilai temannya sendiri menyatakan "kadangkadang" dan $18 \%$ dari 7 responden yang menilai temannya sendiri menyatakan "tidak pernah". Hasil data ini diambil dari jumlah peserta didik yang hadir di kelas yang tidak diberi perlakuan yaitu: kelas VII A yang hadir sebanyak 37 dari 43 peserta didik. (Perhitungan persentase terlampir).

(4) Jumlah yang menilai pada Penyataan Item ke-lima

Pada pernyataan ke-lima peneliti menggunakan pernyataan "Mengucapkan terimakasih setelah menerima bantuan orang lain". Pada pernyataan ini sebanyak $32 \%$ dari 12 responden yang menilai temannya sendiri menyatakan "selalu", $27 \%$ dari 10 responden yang menilai temannya sendiri menyatakan "sering”, 29\% dari 11 responden yang menilai temannya sendiri menyatakan "kadang-kadang” dan $10 \%$ dari 4 responden yang menilai temannya sendiri menyatakan "tidak pernah". Hasil data ini diambil dari jumlah peserta didik yang hadir di kelas yang tidak diberi perlakuan yaitu: kelas VII A yang hadir sebanyak 37 dari 43 peserta didik

Setelah didapatkan hasil sikap sosial selanjutnya melihat hasil realitas pemahaman peserta didik di kelas VII-C, sebagai berikut: 


\section{3) Realitas Pemahaman di kelas yang tidak diberi perlakuan}

Pemahaman Belajar Siswa di kelas yang tidak diberi perlakuan Dengan Menggunakan Model Konvensional Sebelum dan sesudah melalui tes pilihan ganda sebanyak 20 butir soal. Tes tersebut mendapatkan hasil sebagai berikut: dapat dilihat pada tabel 3. dibawah ini:

\section{Tabel 3. Hasil Pemahaman Sebelum dan Sesudah di Kelas Yang Tidak Diberi Perlakuan}

\begin{tabular}{|l|l|l|}
\hline Keterangan & Pretest & Posttest \\
\hline $\mathrm{N}$ & 41 & 41 \\
\hline Nilai Tertinggi & 85 & 55 \\
\hline Nilai Terendah & 40 & 95 \\
\hline Rata-Rata & 62,03 & 78,14 \\
\hline
\end{tabular}

Dari tabel 3. di atas adalah hasil pemahaman belajar siswa kelas VII-A menggunakan model Konvensional pada kegiatan Pretest memiliki nilai tertinggi 85 dan terendah 40, sedangkan rata-ratanya 62,03 kemudian pada kegiatan Post-Test memiliki nilai tertinggi 95 dan terendah 55, sedangkan rata-ratanya 78,14 . Jika terjadi peningkatan pada segi pemahaman maka dapat dilanjut kepada keterampilan praktek, adapun realitas keterampilan praktek, sebagai berikut:

4) Realitas Keterampilan Praktik Shalat Berjamaah dikelas yang tidak diberi perlakuan

Keterampilan Praktek Siswa di kelas yang tidak diberi perlakuan Dengan Menggunakan Model Konvensional Sebelum dan sesudah melalui tes unjuk Kerja. Tes tersebut mendapatkan hasil sebagai berikut: dapat dilihat pada tabel 4. dibawah ini :

\section{Tabel 4. Hasil Praktek Shalat Berjamaah Sebelum dan Sesudah di kelas Yang Tidak Diberi Perlakuan}

\begin{tabular}{|l|l|l|}
\hline Keterangan & Pretest & Posttest \\
\hline $\mathrm{N}$ & 37 & 37 \\
\hline Nilai Tertinggi & 75 & 91 \\
\hline Nilai Terendah & 52 & 76 \\
\hline Rata-Rata & 63,66 & 83,64 \\
\hline
\end{tabular}


Dari tabel 4. di atas adalah hasil keterampilan praktek kelas VII-A menggunakan model Konvensional pada kegiatan Pretest memiliki nilai tertinggi 75 dan terendah 53, sedangkan rata-ratanya 63,66 kemudian pada kegiatan Post-Test memiliki nilai tertinggi 91 dan terendah 76, sedangkan rata-ratanya 83,64

\section{Simpulan}

Proses pembelajaran dengan menggunakan Model Direct Instruction di kelas yang diberi perlakuan dapat dirancang secara bervariasi sesuai dengan materi yang akan disampaikan. Pembelajaran diawali dengan pretest, mengamati tayangan video praktik shalat berjamaah, menanya tentang shalat berjamaah, mengumpulkan informasi berkaitan dengan shalat berjamaah, mengasosiasi dengan kehidupan sehari-hari berkaitan dengan shalat berjamaah, mendemonstrasikan shalat berjamaah dan diakhiri dengan posttest kemudian proses pembelajaran di kelas yang tidak diberi perlakuan model Direct Instruction, pretest, Pemberian materi tetapi tidak diberikan arahan terlebih dahulu karena menggunakan model Konvensional, posttest. Realitas hasil pembelajaran keterampilan praktik shalat berjamaah dengan menggunakan Model Direct Instruction pada kelas yang mendapat perlakuan dapat dikategorikan sedang, dilihat dari rata-rata posttest sebesar 85,78 dan kelas yang tidak mendapat perlakuan dengan model konvensional dikategorikan juga sedang dengan rata-rata 83,64

\section{REFERENSI}

Sulaiman Rasyid, Fiqh Islam, Bandung, Sinar Baru Algensindo, 1994

Abdul Majid \& Chaerul Rochman. 2015. Pendekatan Ilmiah Dalam Implementasi Kurikulum 2013. Bandung : Remaja Rosdakarya

Daryanto, 2011, Media Pembelajaran, Bandung : Sarana Tutorial Nurani Sejahtera.

Darmawan, Deni, 2014, Metode Penelitian Kuantitatif, Bandung : PT Remaja Rosda Karya. 
Indriana, Dina, 2011, Ragam Alat Bantu Media Pengajaran, Yogyakarta : Diva Press.

Kunandar, 2014, Penilaian Autentik (Penilaian Hasil Belajar Peserta Didik Berdasarkan Kurikulum 2013, Jakarta : Rajawali Pers.

Kustandi, Cecep dan Bambang Sutjipto, 2016, Media Pembelajaran Manual dan Digital Edisi Kedua, Bogor : Penerbit Ghalia Indonesia.

Majid, Abdul, 2015, Strategi Pembelajaran, Bandung : PT Remaja Rosda Karya Muhibinsyah, 2016, Psikologi Pendidikan, Bandung : PT Remaja Rosdakarya.

Rusman, 2016, Model-Model Pembelajaran, Jakarta : PT Raja Grafindo.

Sanjaya, wina, 2016, Media Komunikasi Pembelajaran, Jakarta : Kencana Prenada Media Group.

Setiawan, Wawan, dkk, 2010, Penerapan Model Pengajaran Langsung (Direct Instruction) Untuk Meningkatkan Pemahaman Belajar Siswa Dalam Pembelajaran Rekayasa Perangkat Lunak (Rpl), "Jurnal Pendidikan Teknologi Informasi Dan Komunikasi (Ptik)", Vol. 3, No.1, ISSN 1979-9462, Hlm 8.

Usman, 2013, Penerapan Model Direct Instruction untuk Meningkatkan Kemampuan Siswa Menyusun Laporan Keuangan di SMK Negeri 1 Tarakan, "Jurnal Pendidikan Humaniora”, Volume 1, Nomor 3, Hlm 321. 